УДК 336.02

https://doi.org/10.24866/1813-3274/2020-4/60-77

Н. А. Мосолова ${ }^{1}$, Дальневосточный федеральный университет,

г. Владивосток, Россия

E-mail: mosolova.na@dvfu.ru

\title{
АНАЛИЗ СТРУКТУРЫ И ПОКАЗАТЕЛЕЙ ЭКОНОМИЧЕСКОГО ПОТЕНЦИАЛА СФЕРЫ АГРОСТРАХОВЫХ УСЛУГ
}

Аннотация. Опережающие темпы роста объёмов сельскохозяйственного производства сопровождаются увеличением рисков потерь от наступления опасных случайных событий. Важнейшим механизмом защиты имущественных интересов сельхозпроизводителей является страхование. Между тем динамика развития сферы страховых услуг не соответствует темпам развития сельскохозяйственного рынка страны и региональных рынков. В этой связи для формирования эффективных управленческих решений, связанных с развитием сферы агростраховых услуг, необходимо выработать подходы к оценке её экономического потенциала. Практически значимая оценка экономического потенциала невозможна без формирования методологических подходов к определению покомпонентной структуры экономического потенциала, выбора показателей, характеризующих каждую компоненту для расчёта комплексного, интегрального показателя оценки экономического потенциала. В настоящей статье автором предпринята попытка на основании анализа существующих подходов к определению экономического потенциала сформулировать авторскую точку зрения на структуру экономического потенциала сферы страховых услуг для сельхозпроизводителей, в том числе сельхозпроизводителей, осуществляющих свою деятельность на региональных рынках. В статье обосновывается выбор показателей, характеризующих каждую компоненту экономического потенциала сферы агростраховых услуг, оказывающих наибольшее влияние на формирование ключевого показателя экономического потенциала - объёма собираемых страховых премий по страхованию рисков сельхозпроизводителей.

Ключевые слова: сфера агростраховых услуг, риски сельхозпроизводителей, экономический потенциал, компонента, производственный потенциал, финансово-

\footnotetext{
${ }^{1}$ Нина Александровна Мосолова, старший преподаватель Департамента экономических наук Школы экономики и менеджмента Дальневосточного федерального университета, г. Владивосток, Россия.

Для циттирования: Мосолова Н. А. Анализ структуры и показателей экономического потенциала сферы агростраховых услуг // Азиатско-Тихоокеанский регион: экономика, политика, право. 2020. №. 4. C. 60-77. DOI https://doi.org/10.24866/1813-3274/2020-4/60-77

(C) Мосолова Н. А., 2020
} 
инвестиционный потенциал, инновационный потенциал, организационно-управленческий потенциал, сельскохозяйственное производство.

\section{N. A. Mosolova ${ }^{1}$, Far Eastern Federal University, Vladivostok, Russia E-mail: mosolova.na@dvfu.ru}

\section{ANALYSIS OF THE STRUCTURE AND INDICATORS OF ECONOMIC POTENTIAL OF AGRICULTURAL INSURANCE SERVICES}

Abstract. The outstripping growth rates of agricultural production are accompanied by an increase in the risks of losses from the onset of dangerous random events. The most important mechanism for protecting the property interests of agricultural producers is insurance. Meanwhile, the dynamics of the development of insurance services sector does not correspond to the rates of development of the country's agricultural market and regional markets. In this regard, in order to form effective management decisions related to the development of agricultural insurance services, it is necessary to develop approaches to assessing its economic potential. A practically significant assessment of economic potential is impossible without the formation of methodological approaches to determining the component-wise structure of economic potential, the choice of indicators that characterize each component for calculating a complex, integral indicator for assessing economic potential. In this article, the author, based on the analysis of existing approaches to determining the economic potential, has formulated the viewpoint on the structure of economic potential of the insurance services sector for agricultural producers, including agricultural producers operating in regional markets. The article substantiates the choice of indicators that characterize each component of the economic potential of the agricultural insurance sector, which have the greatest impact on formation of the key indicator of economic potential - the volume of collected insurance premiums for insurance of risks of agricultural producers.

Key words: the sphere of agricultural insurance services, risks of agricultural producers, economic potential, component, production potential, financial and investment potential, innovation potential, organizational and managerial potential, agricultural production.

\footnotetext{
1 Nina A. Mosolova, Senior Lecturer, Department of Economic Sciences, School of Economics and Management, Far Eastern Federal University, Vladivostok, Russia.

For citing: Mosolova T. A. Analysis of the structure and indicators of economic potential of agricultural insurance services // PACIFIC RIM: Economics, Politics, Law. 2020. N. 4. P. 60-77. DOI https://doi.org/10.24866/18133274/2020-4/60-77.
} 
Введение. Производство сельскохозяйственной продукции в Российской Федерации, несмотря на все достижения науки, техники и технологии, связано с высоким риском, обусловленным действием различных факторов, как природноклиматического, так и биологического характера, оказывающих негативное влияние на продуктивность и эффективность сельского хозяйства. Большинство территорий страны находится в зоне рискового земледелия. В этих условиях огромное значение имеет страхование сельскохозяйственных рисков, которое смягчает негативное воздействие природно-климатических условий на конечные результаты сельскохозяйственной деятельности.

Анализ показателей, характеризующих динамику развития сферы агростраховых услуг, свидетельствует о крайне низком уровне покрытия рисков сельхозтоваропроизводителей. Несмотря на существенный прирост объёмов сельскохозяйственного производства (в 2019 г. объём произведённой сельхозпродукции 5,9 трлн рублей - в 1,86 раз превышает объём произведённой в 2012 г. сельхозпродукции - 3,16 трлн рублей), страховая сумма страхования агрорисков существенным образом не увеличилась (страховая сумма по всем заключённым в 2019 г. договорам - 458,8 млрд рублей - превышает страховую сумму по договорам, заключенным в 2012 г., - 395,8 млрд рублей, всего на 16\%). Уровень покрытия страхованием сельскохозяйственного производства в России в 2019 г. составил около $12 \%$. Всё это свидетельствует о кризисном развитии сферы агростраховых услуг, о низком уровне экономического потенциала этого сегмента страхового рынка.

Обязательным условием реализации возможностей развития сферы страховых услуг является оценка её экономического потенциала. Оценка экономического потенциала сферы страховых услуг важна для выработки управленческих решений, связанных с развитием, прежде всего, наиболее значимых локальных подсистем - компонент, входящих в состав экономического потенциала. Оценка степени использования экономического потенциала посредством сопоставления фактически достигнутых показателей, характеризующих отдельные подсистемы, с максимально возможными показателями, позволяет выявлять неиспользованные возможности для расширения реализации страховых услуг в сфере сельского хозяйства [25].

Проблема. Для количественного определения потенциала сферы страховых услуг, предоставляемых сельхозпроизводителям на региональных рынках, необходимо определить факторы, которые оказывают влияние на ключевой показатель объём собранных страховых премий. Но экономический потенциал представляет собой многосоставное понятие, включающее разные компоненты экономического потенциала: производственный, финансово-инвестиционный, инновационный, организационно-управленческий. Каждую компоненту экономического потенциала характеризует отдельный набор показателей, учитывающий не только специфику 
развития сферы всех страховых услуг, но и специфику развития отдельного сегмента сферы страховых услуг - страховых услуг сельхозпроизводителей, обоснованный выбор которых позволит провести практически значимую оценку экономического потенциала сферы страховых услуг для сельхозпроизводителей. В настоящее время не существует единых подходов к определению покомпонентной структуры экономического потенциала сферы страховых услуг в целом и сферы агростраховых услуг в частности, что не позволяет выделить показатели, характеризующие каждую компоненты у экономического потенциала сферы страховых услуг, и, следовательно, проанализировать динамику этих показателей с целью определения их влияния на объём потребления страховых услуг сельхозпроизводителями. В свою очередь, отсутствие информации о взаимосвязи и взаимозависимости тех или иных показателей, характеризующих экономический потенциал сферы страховых услуг, не позволяет эффективно и рационально планировать и осуществлять практически значимые мероприятия государственного и регионального масштаба по управлению рисками сельхозпроизводителей.

Цель настоящего исследования - на основе результатов анализа существующих методологических подходов к определению структуры экономического потенциала сферы страховых услуг предложить авторскую трактовку структуры экономического потенциала и набор показателей, характеризующих каждую компоненту экономического потенциала сферы агростраховых услуг.

Обзор литературы. Для выработки авторского определения покомпонентной структуры экономического потенциала обратимся к исследованиям экономистов, изучающих современные аспекты развития сферы агростраховых услуг.

Вопросам сущностного содержания понятия «сфера страховых услуг» посвятили свои труды Н. А. Николаева [16], Н. В. Кучерова [14], В. Б. Гомелля [5], Л. К. Васюкова [4] и др.

Н. В. Кучерова подчёркивает, что в сферу страховых услуг включаются услуги, которые не потребляются в настоящее время отдельными участниками страховых отношений, но могут потребляться в будущем [14].

Н. А. Николаева определяет межотраслевой характер экономических отношений, возникающих в сфере страховых услуг [16].

Л. К. Васюкова в своих работах подчёркивает специфичность сферы страховых услуг, связанную с кредитным характером страховых отношений [4].

В. Б. Гомелля обосновывает состав и структуру страховой услуги, описывает факторы, влияющие на формирование спроса и предложения страховых услуг [5].

Сущностное содержание «экономический потенциал» в своих исследования рассматривали Л. И. Абалкин [1], Б. М. Мочалов [27], П. А. Игнатовский [8], Э. П. Горбунов [6], В. Н. Авдеенко, В. А. Котлов [2], М. С. Остапенко [19] Н. Ф. Колодина [12] и др. 
Обобщая результаты исследований разных экономистов, можно сделать вывод о том, что к раскрытию сущности термина «потенциал» применяется несколько подходов: ресурсный подход (Б. Плышевский [20], А. В. Тодосийчук [22] Е. В. Козина [11], Л. И. Абалкин [1], Г. Б. Клейнер [9]), результативный подход - способность ресурсов в ходе осуществления финансово-хозяйственной деятельности приносить определенные результаты: объем производства, выручка, прибыль (В. Н. Авдеенко [2], И. Н. Богатая [3], Э. П. Горбунов [6], В. А. Котлов [2] и др.), подход к определению потенциала как способностей экономической системы достичь желаемого состояния (В. Н. Мосин [18], Б. М. Мочалов [27], Л. И. Лопатников [15], А. М. Румянцев [28], Д. М. Крук [18], О. В. Козлова [26], Т. Н. Толстых [23], Е. М. Уланова [23]).

Структуру экономического потенциала В. В. Ковалёв раскрывает в своих трудах как совокупность «материальных, трудовых и финансовых ресурсов» [10, с. 263]. И. В. Яроцкий уточняет, что «нематериальная сфера экономического потенциала включает технологии, приемы и методы управления, хозяйственный механизм, традиции, корпоративную культуру и многое другое» [25, с. 57].

P. Т. Юлдашев определяет потенциал сферы страховых услуг как «общий объём рынка страхования за определённый срок, измеренного либо в количестве договоров, либо в единицах стоимости» [24, с. 459].

Определяя подходы к оценке потенциала сферы страховых услуг, Н. В. Кучерова в качестве фактора, влияющего на развитие региональных рынков страховых услуг, выделяет пассивный спрос на страховые услуги и низкий уровень финансовой грамотности большей части потенциальных клиентов страховых компаний [14, с. 153].

Д. В. Пушная и Р. М. Юсупов предлагают для оценки экономического потенциала сферы услуг, как многофакторной системы со сложными разнородными связями, использовать методы корреляционно-регрессионного анализа [21].

И. А. Краснова в методику оценки потенциала сферы страховых услуг предлагает вводить коэффициенты предпочтения страхования перед другими финансовыми услугами [13].

Экономистами P. Картером (R. L. Carter) и Дж. Диккенсоном (G. M. Dickinson) [29] была предложена модель оценки потенциала развития сферы страховых услуг, экономическое содержание которой заключалось в выявлении взаимосвязи между темпом роста проникновения страхования на региональном рынке и уровнем валового регионального продукта (ВРП) на душу населения, проживающего в регионе.

Для оценки экономического потенциала субъектов страхового рынка исследователи предлагают использовать метод главных компонент, методы денежной оценки элементов потенциала [17] и индикативный метод [25], метод интегральной оценки потенциала многомерного динамического объекта в определённый момент времени [7]. 
Между тем, в исследованиях российских и зарубежных экономистов не представлено исчерпывающего обоснования покомпонентной структуры экономического потенциала сферы страховых услуг в общем, так и сферы агростраховых услуг, что затрудняет выбор показателей, для определения ступени влияния их на формирование основной характеристики экономического потенциала сферы - объёма собираемых страховых премий.

Гипотеза исследования. Гипотеза исследования заключается в предположении, что практически значимая оценка экономического потенциала сферы агростраховых услуг является комплексной характеристикой, учитывающей разные компоненты экономического потенциала. Выявление факторов, влияющих на формирование главного показателя, характеризующего экономический потенциал, объёма страховых премий по страхованию рисков агропрозводителей, необходимо для формирования управленческих решений по обеспечению непрерывного производственного процесса по производству сельскохозяйственной продукции в стране и регионе посредством развития сферы агростраховых услуг.

Методы исследования. В процессе исследования применяются общенаучные методы: метод сравнительного анализа (для изучения зарубежного и российского опыта с целью формирования единого вывода об определении и структуре экономического потенциала сферы страховых услуг, используемых в рамках исследования); методы классификации и синтеза (для отбора и изучения показателей, характеризующих отдельные компоненты экономического потенциала сферы агростраховых услуг); методы финансового анализа (для анализа динамики отобранных показателей).

Результаты исследования. Для того, чтобы предложить показатели для оценки потенциала экономического потенциала сферы агростраховых услуг, возникла необходимость уточнения понятия, экономического содержания и покомпонентной структуры экономического потенциала.

Функционирование и развитие страхового рынка как элемента экономической системы возможно при наличии некоторого потенциала. Потенциал в переводе с латинского слова potential означает сила, скрытые возможности.

Как отмечалось ранее, к раскрытию сущностного содержания термина «потенциал» применяется несколько подходов: ресурсный подход, подход к определению потенциала как способностей экономической системы, результативный подход, и подход к потенциалу, как совокупности возможностей.

Специфика оценки экономического потенциала сферы страховых услуг определяется сложной структурой страхового продукта, производимого страховой компанией и реализуемой покупателю на рынке страховых услуг, его невещной формой, вероятностной природой и кредитным характером обязательств участников страховых экономических отношений. 
Учитывая недостатки и разрывы основных подходов к оценке экономического потенциала сферы страховых услуг, предлагаем рассматривать комбинированный или ресурсно-целевой подход к понятию потенциала, включающий в себя как ресурсы, так и способности. Отсюда следует определение экономического потенциала сферы страховых услуг как интегральной характеристики обладания совокупными способностями осуществлять страховую защиту экономических интересов потребителей страховых услуг и наличием реальных возможностей обеспечивать свое устойчивое развитие и достижение стратегических целей на основе рационального использования сформированных ресурсов.

Предлагаемый подход к толкованию содержания экономического потенциала раскрывается через покомпонентную структуру экономического потенциала сферы агростраховых услуг (рис. 1).

Анализ показателей производственного потенцииала. Производственный потенциал, по нашему мнению, характеризует возможность произвести и представить на рынок определённый объём страховых услуг. В свою очередь, производственный потенциал определяется уровнем экономического развития того или иного региона. Таким универсальным макроэкономическим показателем, определяющим уровень экономического развития региона, является показатель, отражающий рыночную стоимость всех конечных товаров и услуг, произведённых в регионе за определённый период, в среднем одним человеком (на душу населения).

По данным Федеральной службы государственной статистики (ФСГС) величина ВВП, или ВРП для региональных экономик, на душу населения постоянно растёт. В период с 2010 г. по 2020 г. показатель ВВП на душу населения в нашей стране увеличился в 2,3 раза. В региональных экономиках динамика показателей ВРП на душу населения также положительна. Так, например, показатель ВРП на душу населения в Приморском крае с 2010 г. по 2020 г. увеличился в 1,8 раза.

Производственный потенциал сферы страховых услуг определяется глубиной проникновения страхования в экономику региона. Главным показателем, характеризующим производственный потенциал сферы агростраховых услуг, является показатель доли страховых премий в объёме валового внутреннего продукта. Для региональных рынков таким показателем является величина доли страховых премий в объёме валового регионального продукта.

Ещё одним важным для оценки производственного потенциала сферы страховых услуг является показатель глубины проникновения страхования в экономику региона. В работах Дж. Диккинсона - Р. Картера [29] обосновывается тезис о взаимосвязи изменения показателя ВВП (ВРП) на душу населения с изменением показателя глубины проникновения страхования в экономику региона: при росте ВВП (ВРП) на душу населения значение показателя проникновения страхования также увеличивается. 


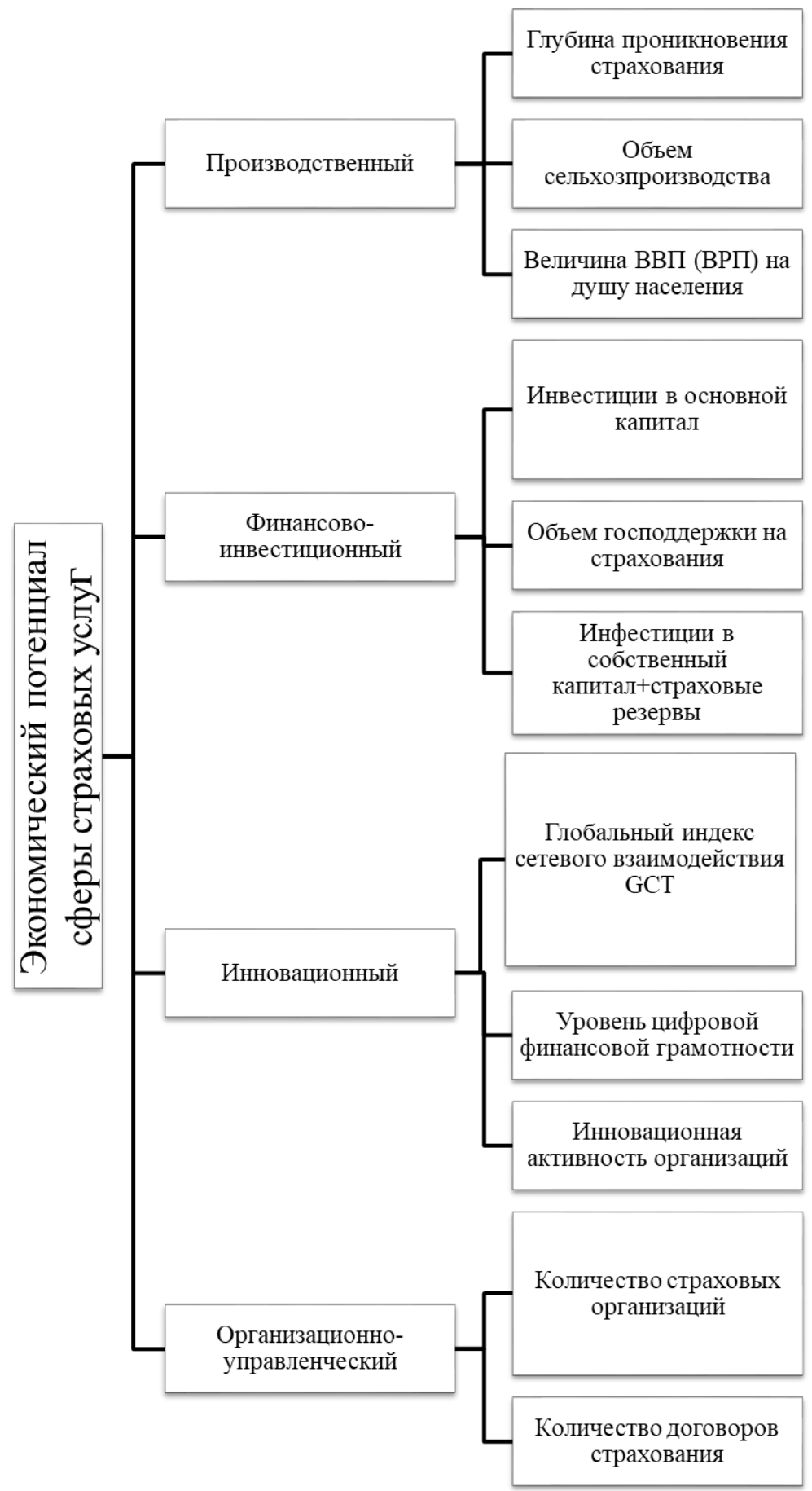

Puc. 1. Структура экономического потенциала сферы агростраховых услуг Источник: разработано автором 
Анализ динамики показателя глубины проникновения страхования в экономику - отношения величины собираемых страховых премий к величине ВВП свидетельствует о том, что темпы роста данного показателя (показатель глубины проникновения в 2019 г. превышает аналогичный показатель в 2010 г. на 11,5\%) в исследуемом периоде значительно ниже темпов роста показателя ВВП на душу населения.

Ещё одним показателем, характеризующим производственный потенциал сферы страховых услуг, является объём производства сельскохозяйственной продукции в регионе. Чем выше объём производимой продукции, тем выше уровень рисков потерь, связанных с наступлением опасных случайных событий: стихийных бедствий, болезней и гибели сельскохозяйственных животных, пожаров и др. Увеличение вероятности наступления страховых событий и величины убытков, получаемых сельхозпроизводителями, от опасных случайных событий, увеличивает потребность в приобретении страховой защиты.

Темпы роста объёма сельхозпроизводства в России в период с 2010 г. по 2019 г. (в 2010 г. объём сельхозпроизводства составил 2,46 трлн р., в 2019 г. 5,91 трлн р.) сопоставимы с темпами роста показателя ВВП на душу населения в исследуемом периоде.

Взаимосвязь между объёмом собираемых страховых премий по агрострахованию и величиной сельхозпроизводства в стране или регионе выражается посредством показателя глубины проникновения страховых услуг на рынок сельхозпроизводства.

Анализ динамики данного показателя свидетельствует о том, что показатель в течение всего исследуемого периода уменьшался. Несмотря на существенный прирост объёмов сельскохозяйственного производства (в 2019 г. объём произведённой сельхозпродукции - 5 907,9 млрд руб. - в 1,86 раз превышает объём произведённой сельхозпродукции в 2012 г. - 3 160,3 млрд руб.), страховая сумма страхования агрорисков существенным образом не увеличилась (страховая сумма по всем заключённым в 2019 г. договорам - 458,86 млрд руб. - превышает страховую сумму по договорам, заключённым в 2012 г., - 395,78 млрд руб. - в 1,16 раз).

Уровень страхового покрытия сельскохозяйственного производства к 2020 г. снизился практически в 1,6 ра3 - с 12,53\% в 2012 г. до 7,77\% в 2019 г.

Анализ показателей организаиионно-управленческого потенииала. Важнейшей компонентой экономического потенциала является организационноуправленческий потенциал сферы страховых услуг.

Количество страховых организаций, имеющих лицензию на страхование сельскохозяйственных рисков, страховые продукты, квалифицированный персонал, мотивированных на увеличение числа договоров страхования в своём сегменте рынка, является важнейшей характеристикой организационно-управленческого потенциала. 
Количество страховщиков, имеющих лицензию на страхование сельхозрисков, за последние десять лет сократилось практически в 3 раза: с 68 субъектов сферы страховых услуг в 2010 г. до 24 - в 2020 г. Количество сделок по заключению страховых контрактов с сельхозпроизводителями в исследуемом периоде сократилось в 4,8 раза: с 247 тыс. договоров в 2010 г. до 51 тыс. договоров в 2020 г.

Сокращение количества страховщиков, работающих в том или ином сегменте рынка, приводит к перераспределению между оставшимися участниками высвободившейся доли рынка. Изменение количества участников сферы страховых услуг ведёт к изменению показателей концентрации рынка - коэффициента Херфиндаля - Хиршмана (рис. 2).

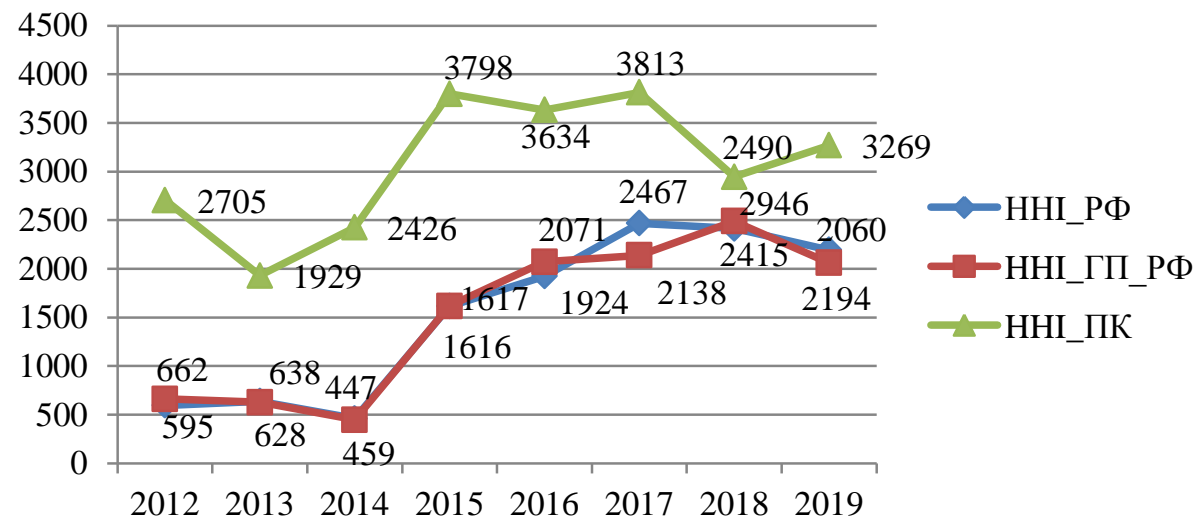

Рис. 2. Динамика коэффициента Херфиндаля - Хиршмана сферы агростраховых услуг в России (ННІ_РФ), в том числе страхования, осуществляемого с господдержкой (ННI_ГП_РФ), агрострахования в Приморском крае Источник: разработано автором по [24]

Анализ динамики коэффициента НHI свидетельствует о высокой монополизации сферы агростраховых услуг. Динамика коэффициента концентрации сферы страховых услуг CR-4 и CR-8 (рис. 2) свидетельствует о том, что, начиная с 2016 г. сфера агростраховых услуг приобретает по степени монополизации по трёхпороговой оценочной шкале Бейна признаки высококонцентрированной олигополии.

Анализ показателей финансово-инвестиционного потенциала. Финансовоинвестиционный потенциал сферы страховых услуг обусловлен способностью участников страховых отношений, как страховщиков, так и агропроизводителейстрахователей привлекать и использовать финансовые ресурсы.

Основными инвестиционными ресурсами страховщика являются страховые резервы и собственный капитал страховщика. 
Анализ изменения величины страховых резервов в период 2010-2020 гг. свидетельствует о высокой волатильности величины резервных фондов страховщиков. Наибольший размер страховых резервов по сегменту агрострахования был сформирован в 2011 и 2014 гг. - более 9 млрд руб. В целом же величина совокупных страховых резервов в исследуемом периоде снизилась почти в 2 раза и по состоянию на начало 2020 г. составила 3,17 млрд руб.

Капитализация страховщиков агрорисков в последние 10 лет выросла на 18\%, до 95,9 млрд рублей, несмотря на снижение количества субъектов - поставщиков страховых услуг.

Страховые выплаты, которые производятся страховщиками при наступлении страховых событий, также характеризуют финансово-инвестиционный потенциал сферы страховых услуг, поскольку могут рассматриваться как внебюджетный источник инвестиций в покрытие убытков агропроизводителей от наступления опасных случайных событий. Динамика величины страховых выплат повторяет тренд изменения величины страховых премий: от 7,7 млрд руб. в 2010 г. до 2,0 млрд руб. в 2019 г.

Объём субсидий на возмещение части затрат сельхоз товаропроизводителей на уплату страховых премий по заключенным договорам сельскохозяйственного страхования характеризует способность сферы страховых услуг привлекать бюджетные источники для увеличения экономического потенциала страхового рынка, основной характеристикой которого является показатель ёмкости рынка - собираемых страховых премий.

Следует отметить, что и показатель, характеризующий объём субсидий на возмещение затрат по уплате сельхозпроизводителями страховых премий повторяет тренд изменения величины страховых премий. Наибольшая величина субсидий была выделена государством в 2014 г. - 5,0 млрд руб., наименьшая величина субсидий выделена в 2017 г. - 727 млн руб.

Объем субсидий на возмещение части затрат сельхоз товаропроизводителей на уплату страховых премий по заключенным договорам сельскохозяйственного страхования характеризует способность сферы страховых услуг привлекать бюджетные источники для увеличения экономического потенциала страхового рынка, основной характеристикой которого является показатель ёмкости рынка - собираемых страховых премий.

Инвестиции в основной капитал сельхозпроизводителей являются одним из главных факторов экономического роста сельскохозяйственного рынка сельхозпроизводства, а, следовательно, потребности в защите имущественных интересов агропроизводителей посредством приобретения страховых услуг. В качестве показателя, характеризующего финансово-инвестиционный потенциал сферы агростраховых услуг, автором выбран показатель - индекс инвестиций в основной капитал (в \% к предыдуще- 
му году). Наибольшие темпы роста инвестиций в основной капитал сельхозпроизводителей наблюдался в 2011 г. - 134,8\%. В 2010, 2014-2015 гг., в 2019 г. инвестиции в основной капитал были ниже уровня, достигнутого в предыдущий год.

Инновационный потенциал определяется способностью участников страховых отношений - страховщиков и страхователей - создать и потребить новые страховые продукты, способы их распространения, использования для защиты имущественных интересов агропроизводителей.

В настоящее время определяющими факторами, влияющими на развитие всех сегментов сферы страховых услуг, являются процессы цифровизации рынка. Инновационный потенциал сферы страховых услуг определяется процессами цифровизации, формирующими новые экономические отношения между поставщиком и потребителем страховых услуг - с использованием цифровых технологий.

Инновационный потенциал сферы страховых услуг может характеризоваться следующими показателями: Глобальный индекс сетевого взаимодействия (Global Connectivity Index - GCI), [15]; индекс цифровой и финансовой грамотности потребителей финансовых услуг; число абонентов фиксированного широкополосного доступа в Интернет на 100 чел. населения (целевой индикатор реализации Стратегии инновационного развития РФ).

Несмотря на то, что статистика по многим показателям, характеризующим инновационный потенциал сферы страховых услуг, стала формироваться в последние 5 лет, считаем важным при оценке экономического потенциала сферы страховых услуг учитывать влияние этих показателей на конечный, интегральный показатель оценки экономического потенциала.

В табл. 1 приведена сводная выборка показателей, характеризующих компоненты экономического потенциала сферы агростраховых услуг.

Таблица 1

\section{Выборка показателей, характеризующих компоненты экономического потенциала сферы страховых услуг на сельскохозяйственных рынках}

\begin{tabular}{|c|c|}
\hline Показатель & Отражение потенциала \\
\hline Объем страховых премий по агрострахованию & $\begin{array}{l}\text { Экономический потенциал сферы } \\
\text { страховых услуг }\end{array}$ \\
\hline ВВП на душу населения & \multirow[t]{4}{*}{ Производственный потенциал } \\
\hline $\begin{array}{l}\text { Глубина проникновения страховых услуг } \\
\text { в экономику (СП/ВВП (ВРП) }\end{array}$ & \\
\hline Объём сельхозпроизводства в текущих ценах (ОСП) & \\
\hline $\begin{array}{l}\text { Глубина проникновения страховых услуг на рынок } \\
\text { производства сельхозпродукции (ССП агро / ОСП) }\end{array}$ & \\
\hline
\end{tabular}


Окончание табл. 1

\begin{tabular}{|c|c|}
\hline Показатель & Отражение потенциала \\
\hline $\begin{array}{l}\text { Индекс инвестиций в основной капитал } \\
\text { (в \% к предыдущему году) }\end{array}$ & \multirow[t]{5}{*}{$\begin{array}{l}\text { Финансово-инвестиционный } \\
\text { потенциал }\end{array}$} \\
\hline $\begin{array}{l}\text { Сумма субсидий на возмещение части затрат } \\
\text { сельхозтоваропроизводителей на уплату страховых } \\
\text { премий по заключённым договорам } \\
\text { сельскохозяйственного страхования }\end{array}$ & \\
\hline $\begin{array}{l}\text { Величина собственного капитала страховых } \\
\text { компаний - страховщиков рисков агропроизводителей }\end{array}$ & \\
\hline $\begin{array}{l}\text { Величина страховых резервов по страхованию рисков } \\
\text { агропроизводителей }\end{array}$ & \\
\hline Страховые выплаты по договорам агрострахования & \\
\hline $\begin{array}{l}\text { Количество страховых компаний, имеющих лицензию } \\
\text { на агрострахование }\end{array}$ & \multirow[t]{3}{*}{$\begin{array}{l}\text { Организационно-управленческий } \\
\text { потенциал }\end{array}$} \\
\hline Количество договоров агрострахования & \\
\hline $\begin{array}{l}\text { Коэффициент Херфиндаля - Хиршмана сферы } \\
\text { агростраховых услуг РФ }\end{array}$ & \\
\hline $\begin{array}{l}\text { Глобальный индекс сетевого взаимодействия (Global } \\
\text { Connectivity Index - GCI) }\end{array}$ & \multirow[t]{4}{*}{ Инновационный потенциал } \\
\hline Индекс цифровой грамотности & \\
\hline Индекс финансовой грамотности & \\
\hline $\begin{array}{l}\text { Число абонентов фиксированного широкополосного } \\
\text { доступа в Интернет (на } 100 \text { чел. населения), целевой } \\
\text { индикатор Стратегии инновационного развития РФ }\end{array}$ & \\
\hline
\end{tabular}

Источник: составлено автором

\section{Выводы}

1. Экономический потенциал сферы страховых услуг имеет сложную структуру, включающую следующие компоненты: производственный, финансово-инвестиционный, организационно-управленческий, инновационный потенциал.

2. Для выполнения комплексной оценки экономического потенциала сферы агростраховых услуг необходимо провести анализ его элементов по группам показателей.

3. Практически значимая оценка экономического потенциала возможна при условии установления взаимосвязи и взаимовлияния между его компонентами и формирования комплексного, интегрального показателя количественной оценки экономического потенциала сферы страховых услуг на сельскохозяйственных рынках. 
Поскольку большинство территорий нашей страны находятся в зоне рискового земледелия, то в этих условиях важнейшим механизмом защиты имущественных интересов сельхозпроизводителей станет страхование.

\section{Список литературы}

1. Абалкин, Л. И. Интенсификация и экономический рост / Л. И. Абалкин // Плановое хозяйство - 1985. - № 8. - С. 18-26.

2. Авдеенко, В. Н. Производственный потенциал промышленного предприятия / В. Н. Авдеенко, В. А. Котлов. - Москва : Экономика, 1989. - 239 с.

3. Богатая, И. Н. Стратегический учет собственности предприятия / И. Н. Богатая. - Ростов-на-Дону : Феникс, 2001. -317 с.

4. Васюкова, Л. К. Об особенностях страхового товара как средства достижения целей участников страховых отношений / Л. К. Васюкова, Л. И. Матузенко, Н. А. Мосолова // Экономика и предпринимательство. - 2017. - № 2-1 (79-1). C. $785-788$.

5. Гомелля, В. Б. Очерки экономической теории страхования / В. Б. Гомелля ; под ред. Е. В. Коломина. - Москва : Финансы и статистика, 2010. - 310 с.

6. Горбунов, Э. П. Экономический потенциал развитого социалистического общества // Вопросы экономики. - 1981. - № 9. - С. 100-101.

7. Джурабаева, Г. К. Интегральная оценка экономического потенциала организации / Г. К. Джурабаева, В. О. Шаланов // Сибирская финансовая школа. - 2009. № 3 (74). - С. 135-138.

8. Игнатовский, П. А. Экономический потенциал и условия действенности хозяйственного механизма // Плановое хозяйство. - 2019. - № 2. - С. 76-92.

9. Клейнер, Г. Б. Предприятие в нестабильной экономической среде: риски, стратегия, безопасность / Г. Б. Клейнер, В. Л. Тамбовцев, Р. М. Качалов. - Москва : Экономика, 1997. - 298 с.

10. Ковалев, В. В. Финансовый анализ: методы и процедуры / В. В. Ковалев. Москва : Финансы и статистика, 2005. - 560 с.

11. Козина, Е. В. Проблемы определения и оценки экономического потенциала региона / Е. В. Козина, С. В. Гостева // Интернет-журнал «Науковедение»2016. - T. 8, № 5. - URL: http://naukovedenie.ru/PDF/99EVN516.pdf (дата обращения: 27.12.2020).

12. Колодина, Н. Ф. Методика исследования потенциала регионального продовольственного рынка // Экономические науки. - 2014. - № 2. - С. 197-200.

13. Краснова, И. А. Исследование страхового поля // Страховое ревю. 1997. - № 3. - С. 25-30.

14. Кучерова, Н. В. Методологический подход к систематизации методов анализа рынка страховых услуг и методика изучения его потенциала // Известия Орен- 
бургского государственного аграрного университета. - 2010. - № 25-1. C. $153-155$.

15. Лопатников, Л. И. Популярный экономико-математический словарь / Л. И. Лопатников. - Москва : Знание, 1990. - 251 с.

16. Николаева, Н. А. Страхование как инструмент сглаживания пространственной поляризации // Вектор науки Тольятинского государственного университета. - 2012. - № 1(19). - С. 167-169.

17. Никулина, Н. Н. Инвестиционный потенциал страховщиков: сущность и инвестиционные возможности / Н. Н. Никулина, И. И. Ушаков // Вестник Московского университета МВД России. - 2015. - № 5. - С. 167-171.

18. Основы экономического и социального прогнозирования / под ред. В. Н. Мосина, Д. М. Крука. - Москва : Высшая школа, 1985 - 200 с.

19. Остапенко, М. С. Экономический потенциал как объект управления // Современные научные исследования и инновации. -2015 . - № 12 - С. 707-713.

20. Плышевский, Б. Потенциал инвестирования // Экономист. - 1996. - № 3. C. $3-17$.

21. Пушная, Д. В. Оценка экономического потенциала эффективности функционирования предприятий и отраслей сферы услуг / Д. В. Пушная, Р. М. Юсупов // Управление экономическими системами : электронный научный журнал. - 2014. № 2 (62). - URL: https://www.elibrary.ru/item.asp?id=21569420 (дата обращения: 27.12.2020).

22. Тодосийчук, А. Научно-технический потенциал социально-трудовой сферы // Экономист. - 1997. - № 12. - С. 63-72.

23. Толстых, Т. Н. Проблемы оценки экономического потенциала предприятия: финансовый потенциал / Т. Н. Толстых, Е. М. Уланова // Вопросы оценки. 2004. - № 4. - С. 18-22.

24. Юлдашев, Р. Т. Страховой бизнес : словарь-справочник / Р. Т. Юлдашев. Москва : АНКИЛ, 2005. -832 с.

25. Яроцкий, И. В. Методический подход к оценке финансового потенциала страховой организации // Вестник Тихоокеанского государственного экономического университета. - 2012. - № 3. - С. 55-63.

26. Управление социалистическим производством : словарь / под ред. О. В. Козловой. - Москва : Экономика, 1983. - 335с.

27. Экономический потенциал развитого социализма / под ред. Б. М. Мочалова. - Москва : Экономика, 1982. -278 с28. Экономическая энциклопедия. Т. 4 : Политическая экономия / под ред. А. М. Румянцева. - Москва : Советская энциклопедия, 1983. - $672 \mathrm{c.}$

29. Carter, R. L. Obstacles to the liberalization of trade in insurance / R. L. Carter, G. M. Dickinson. - London : Harvester Wheatsheaf, 2002. - 191 p. 
30. Global Connectivity Index - GCI. - URL: https://www.huawei.com/minisite/r ussia/gci2018rus/huaweiGCI.html (дата обращения: 07.07.2020).

\section{References}

1. Abalkin L. I. Intensifikatsiya i ekonomicheskii rost [Intensification and economic growth]. Planovoe khozyaistvo, 1985, no. 8, pp. 18-26.

2. Avdeenko V. N., Kotlov V. A. Proizvodstvennyi potentsial promyshlennogo predpriyatiya [The production potential of an industrial enterprise]. Moscow: Ekonomika Publ., 1989. 239 p.

3. Bogataya I. N. Strategicheskii uchet sobstvennosti predpriyatiya [Strategic accounting of the property of the enterprise]. Rostov-on-Don: Feniks Publ., 2001. 317 p.

4. Vasyukova L. K., Matuzenko L. I., Mosolova N. A. Ob osobennostyakh strakhovogo tovara kak sredstva dostizheniya tselei uchastnikov strakhovykh otnoshenii [On the peculiarities of the insurance product as a means of achieving the goals of participants in insurance relations]. Ekonomika i predprinimatel'stvo, 2017, no. 2-1 (79-1), pp. $785-788$.

5. Gomell V.B. Ocherki ekonomicheskoi teorii strakhovaniya [Essays on the economic theory of insurance]. Moscow: Finansy i statistika Publ., 2010. 310 p.

6. Gorbunov E.P. Ekonomicheskii potentsial razvitogo sotsialisticheskogo obshchestva [Economic potential of a developed socialist society]. Voprosy ekonomiki, 1981, no. 9, pp. 100-101.

7. Dzhurabaeva G. K., Shalanov V. O. Integral'naya otsenka ekonomicheskogo potentsiala organizatsii [Integral assessment of the economic potential of the organization]. Sibirskaya finansovaya shkola, 2009, no. 3 (74), pp. 135-138.

8. Ignatovsky P. A. Ekonomicheskii potentsial i usloviya deistvennosti khozyaistvennogo mekhanizma [Economic potential and conditions for the effectiveness of the economic mechanism]. Planovoe khozyaistvo, 2019, no. 2, pp. 76-92.

9. Kleiner G. B., Tambovtsev V.L., Kachalov R.M. Predpriyatie v nestabil'noi ekonomicheskoi srede: riski, strategiya, bezopasnost' [Enterprise in an unstable economic environment: risks, strategy, security]. Moscow: Ekonomika Publ., 1997. 298 p.

10. Kovalev V. V. Finansovyi analiz: metody i protsedury [Financial analysis: methods and procedures]. Moscow: Finansy i statistika Publ., 2005. 560 p.

11. Kozina E. V., Gosteva S. V. Problemy opredeleniya i otsenki ekonomicheskogo potentsiala regiona [Problems of determining and assessing the economic potential of the region]. Naukovedenie: internet-journal, 2016, vol. 8, no. 5. Availabe at: http://naukovedenie.ru/PDF/99EVN516.pdf (accessed 27 December 2020).

12. Kolodina N. F. Metodika issledovaniya potentsiala regional'nogo prodovol'stvennogo rynka [Methods of researching the potential of the regional food market]. Ekonomicheskie nauki, 2014, no. 2, pp. 197-200. 
13. Krasnova I. A. Issledovanie strakhovogo polya [Research of the insurance field]. Strakhovoe revyu, 1997, no. 3, pp. 25-30.

14. Kucherova N. V. Metodologicheskii podkhod k sistematizatsii metodov analiza rynka strakhovykh uslug i metodika izucheniya ego potentsiala [Methodological approach to the systematization of methods for analyzing the market of insurance services and methods of studying its potential]. Izvestiya Orenburgskogo gosudarstvennogo agrarnogo universiteta, 2010, no. 25-1, pp. 153-155.

15. Lopatnikov L. I. Populyarnyi ekonomiko-matematicheskii slovar' [Popular economic and mathematical dictionary]. Moscow: Znanie Publ., 1990. 251 p.

16. Nikolaeva N. A. Strakhovanie kak instrument sglazhivaniya prostranstvennoi polyarizatsii [Insurance as a tool for smoothing spatial polarization]. Vektor nauki Tol'yatinskogo gosudarstvennogo universiteta, 2012, no. 1 (19), pp. 167-169.

17. Nikulina N. N., Ushakov I. I. Investitsionnyi potentsial strakhovshchikov: sushchnost' i investitsionnye vozmozhnosti [Investment potential of insurers: essence and investment opportunities]. Vestnik Moskovskogo universiteta MVD Rossii, 2015, no. 5, pp. $167-171$.

18. Mosin V. N., Kruk D. M. Osnovy ekonomicheskogo i sotsial'nogo prognozirovaniya [Fundamentals of economic and social forecasting]. Moscow: Vysshaya shkola, 1985. $200 \mathrm{p}$.

19. Ostapenko M. S. Ekonomicheskii potentsial kak ob"ekt upravleniya [Economic potential as an object of management]. Sovremennye nauchnye issledovaniya $i$ innovatsii, 2015, no. 12, pp. 707-713.

20. Plyshevsky B. Potentsial investirovaniya [Investment potential]. Ekonomist, 1996, no. 3, pp. 3-17.

21. Pushnaya D. V., Yusupov R. M. Otsenka ekonomicheskogo potentsiala effektivnosti funktsionirovaniya predpriyatii i otraslei sfery uslug [Assessment of the economic potential of the efficiency of the functioning of enterprises and service industries]. Upravlenie ekonomicheskimi sistemami: electronic scientific journal, 2014, no. 2 (62). Available at: https://www.elibrary.ru/item.asp?id=21569420 (accessed 27.12.2020).

22. Todosiychuk A. Nauchno-tekhnicheskii potentsial sotsial'no-trudovoi sfery [Scientific and technical potential of the social and labor sphere]. Ekonomist, 1997, no. 12, pp. 63-72.

23. Tolstykh T. N., Ulanova E. M. Problemy otsenki ekonomicheskogo potentsiala predpriyatiya: finansovyi potentsial [Problems of assessing the economic potential of the enterprise: financial potential]. Voprosy otsenki, 2004, no. 4, pp. 18-22.

24. Yuldashev R. T. Strakhovoi biznes: slovar'-spravochnik [Insurance business: dictionary-reference book]. Moscow: ANKIL Publ., 2005. 832 p.

25. Yarotsky I. V. Metodicheskii podkhod $\mathrm{k}$ otsenke finansovogo potentsiala strakhovoi organizatsii [Methodological approach to assessing the financial potential of 
an insurance organization]. Vestnik Tikhookeanskogo gosudarstvennogo ekonomicheskogo universiteta, 2012, no. 3, pp. 55-63.

26. Kozlova O. V., ed. Upravlenie sotsialisticheskim proizvodstvom: slovar' [Management of socialist production: dictionary]. Moscow: Ekonomika Publ., 1983. 335 p.

27. Mochalov B. M., ed. Ekonomicheskii potentsial razvitogo sotsializma [The economic potential of developed socialism]. Moscow: Ekonomika Publ., 1982. 278 p.

28. Rumyantsev A. M., ed. Ekonomicheskaya entsiklopediya. T. 4: Politicheskaya ekonomiya [Economic encyclopedia. Vol. 4: Political Economy]. Moscow: Sovetskaya entsiklopediya Publ., 1983. 672 p.

29. Carter R. L., Dickinson G. M. Obstacles to the liberalization of trade in insurance . London: Harvester Wheatsheaf, 2002. $191 \mathrm{p}$.

30. Global Connectivity Index - GCI. Available at: https://www.huawei.com /minisite/russia/gci2018rus/huaweiGCI.html (accessed 07 July 2020). 